\title{
Bacterial Diseases Affecting Egg Production of Laying Hens
}

\author{
Sibel Yaman ${ }^{1}$ and Ozlem Sahan Yapicier ${ }^{2 *}$ \\ ${ }^{1}$ Burdur Mehmet Akif Ersoy University, The Health Sciences Institute,Department of Microbiology, 15030, Burdur Province, Turkey \\ ${ }^{2}$ Burdur Mehmet Akif Ersoy University, Faculty of Veterinary Medicine, Department of Microbiology, 15030, Burdur Province, Turkey
}

Submission: April 15, 2019; Published: April 26, 2019

*Corresponding author: Özlem Şahan Yapicier, Burdur Mehmet Akif Ersoy University, Faculty of Veterinary Medicine, Department of Microbiology, 15030, Burdur Province, Turkey

Abstract

Common health disorders for poultry industry also have specific effects on egg production. Infectious diseases, which will be among these problems, affect the reproductive system negatively by directly affecting the health status of the animal or animal and decreasing the egg quality. Especially, bacterial pathogens affect the reproductive system, the ovaries and oviduct initially. In fact, it is aimed to emphasize the importance of development of diagnostic methods of diseases, knowledge of epidemiology of diseases, diagnosis of early stage of disease, constantly trained with updated information of disease prevention based on scientific principles to technical personnel.

Keywords: Layers; Egg production; Bacterial disease

\section{Introduction}

There are several issues that can affect egg production in laying hens, including management errors (lighting errors, incorrect temperature settings or ventilation, incorrect feeding, equipment errors), and infectious and non-infectious agents, which can cause sudden and dramatic decreases in egg production [1]. Among the measures that should be taken to eliminate the cause of the decrease in egg production, recording changes in nutrition, behavior or appearance are primary [2]. Some of the major health concerns in the poultry sector also affect egg production. Infectious diseases, which can be considered among these concerns, decrease egg production and quality directly by affecting the genital system, or indirectly, affecting the health status of the animals.

\section{Bacterial Diseases}

\section{Colibacillosis}

This is a disease that is characterized by colisepticemia, hemorrhagic septicemia, coligranuloma, air sac disease, swollen head syndrome, venereal colibacillosis, cellulitis, peritonitis, salpingitis, osteomyelitis, yolk sac infection and enteritis caused by the avian pathogenic Escherichia coli (APEC) of the Enterobacteriaceae family. APEC is often isolated from avian species, while 01, 02, 08, 015, 018, 035, 078, 088, 0109 and 0115 serogroups of the 0 antigen are usually isolated. 02 and 078 are serogroups that are usually isolated and comprise $80 \%$ of the cases worldwide [6]. E. coli is present in the gastrointestinal tract of most animals and it is excreted in high amounts through feces [7]. After intake, its colonization in the trachea, caecum and oviduct takes around 21 weeks
[8]. Transmission can occur through contact with infected animals or through the intake of water and feed contaminated with feces, as well as via the inhalation of agents from dust and bedding materials [8]. Transmission can also occur when oophoritis and salphingitis develop in laying fowl breeds, prior to the formation of the eggshell, or after it has been formed while passing through the cloaca [7].

Inflammation in the oviduct due to APEC results in the reduction of egg production and sporadic mortality [7]. Exudate, which accumulates with the inflammation that occurs as a result of egg peritonitis causes formation of egg yolk that coagulates in the body. In addition, colisepticemia, which affects egg production, can often be seen in young laying hens, but rarely in mature animals [9].

\section{Salmonella Infection}

These are infections caused by Salmonella Gallinarum ( $S$. Gallinarum) and Salmonella Pullorum (S.Pullorum), and include pullorum disease (PD), fowl typhoid (FT) and infections of chicks and hens that are characterized with septicemia [10]. Adult fowl are prone to fowl typhoid, while young fowl are prone to pullorum disease. The transmission sources of Salmonella Gallinarum ( $S$. Gallinarum) are hatcheries, feed and poultry houses [11,12]. On the other hand, Salmonella Pullorum(S. Pullorum) transmission can occur within 48 hours of hatching, in which case shell penetration and feed contamination occur at a lower rate [12]. $S$. Pullorum localizes in the reproductive tract of layers, and more densely in the ovary and oviduct with sexual maturation [10]. 
Amorphous and cystic follicles can cause minimal lesions such as small nodules or regression of ovarian follicles and can be seen when chronic infection occurs. In this case, the oviduct fills with a caseous exudate, causing the disfunction of the ovary and oviduct, thus leading to peritonitis [10].

\section{Fowl Cholera}

This is a septicemic disease of domestic and wild fowl with high mortality and morbidity rates, caused by Pasteurella multocida (P. multocida) of the Pasteurellaceae family [9]. Adult chickens are more prone than young fowl [9], and broilers are more resistant to the disease than layers, resulting in deaths at higher rates in laying hens [13]. Transmission occurs through the digestive tract, respiratory tract, skin and conjunctiva, and is particularly transmitted through the feces or oral/nasal discharge of animals that have recovered from the infection [9]. The ovaries are infected cases of acute cholera in laying hens. Matured follicles take on a flabby and densely vascularized appearance, and the follicular content is released into the peritoneum as soon as the follicles rupture. The stroma of unmatured follicles and ovaries are hyperemic, which leads to a decrease in production in laying hens [8].

\section{Gallibacterium anatis infection}

Gallibacterium anatis (G. anatis) of the Pasteurellaceae family was known previously as Pasteurella anatis [14]. Gallibacterium has been reported in many countries around the world [11], with age, stress, weakened immunity status and hormonal factors all being effective in disease occurrence. In addition to chickens, other avian species, such as duck, turkey, pheasant a partridge, are prone to $G$. anatis $[15,16]$. The horizontal route is effective in the transmission of the disease. Although uncommon in the Pasteurellaceae family, trans-ovarian infection, which supports vertical transmission, has been proven for G. anatis [16], and this was confirmed in particular with the isolation of the agent from the yolk sac of a four-day old chick. A decrease in egg production is seen in the peak period of chickens caused by lesions such as folliculitis, and ruptures and hemorrhagic follicles that occur in the genital tract of adult laying hens $[16,17]$.

\section{Infectious Coryza}

Chickens are natural hosts of the agent Avibacterium paragallinarum (A.paragallinarum) [8]. The disease is characterized by a swelling around the eyes and face. The agent is transmitted through secretions and excretions between animals. Transmission can also occur through the exchange of machinery/equipment between farms, and also by personnel [15]. It causes a $10-40 \%$ decrease in egg production. Morbidity of the disease is $80-100 \%$, while mortality is around $10 \%$ [8].

\section{Mycoplasma Infection}

Mycoplasma synoviae (MS) and Mycoplasma gallisepticum (MG) are the cause of mycoplasma infections, for which chickens are natural hosts MG causes chronic respiratory infections [8]. The primary symptoms are coughing, panting, slight opening of the beak and reduction in feed intake [11]. Decrease in egg produc- tion, co-inflammation of the cornea and conjunctiva, facial edema and tear secretion are clinically apparent [16]. Oviduct thickening and salphingitis in laying hens are considered to be causes of decreases in production. Chicks that hatch from the eggs of infected animals play a significant role in lateral transmission. The most significant route is transmission through eggs. Vertical transmission through infected eggs is observed $[16,17]$.

MS infection is seen in chickens older than 4 weeks of age. It is usually an upper respiratory tract infection [11]. Strains isolated in recent years were frequently isolated from flocks with decreased egg production and egg defects $[16,17]$. The agent causes the eggshell to become thinner, to lose opacity and to develop a rough surface. Thus, eggs tend to crack or break more easily. The agent causes more than $10 \%$ of eggs to be unfertilized as well as a decrease in egg production [16].

\section{Ornithobacterium rhinotracheale(ORT) Infection}

This is a contagious, fatal respiratory disease that causes growth deficiency. Its natural hosts are chickens and turkeys [18]. ORT can be transmitted vertically, but also horizontally through aerosols or drinking water. The agent can be isolated from the ovary, oviduct, hatching eggs and unfertilized eggs. A production decrease in commercial layers, an increase in the number of eggs of smaller size than normal and changes in shell quality are among the clinical symptoms of the disease [18].

\section{Conclusion}

It has been demonstrated that egg production loss can be attributed to several causes other than management error in establishments, with infectious agents led by bacterial and viral diseases emphasized in particular. When infectious factors affecting egg production are considered individually, the measures to be taken in poultry houses should be considered more significant than the treatment of disease. All efforts aimed at controlling disease agents should be considered within the scope of biosecurity, including the prevention of entry of disease agents into the establishment, the prevention of transmission of the disease to healthy animals in the event of a disease outbreak, the taking of measures to prevent contaminated materials from disseminating into the environment and the elimination of disease agents from the environment are necessary. Accordingly, every poultry house/establishment should prepare a biosecurity plan. A protection, control and eradication program should be implemented with information obtained from a monitoring of the diseases that affect egg production. In this regard, the development of disease diagnostic methods, the gaining of knowledge of disease epidemiology's, early disease diagnosis and training of technical personnel with new and updated information are considered necessary.

\section{References}

1. Spitzer H (2015) An analysis of bacterial contamination of chicken eggs and antimicrobial resistance. Celebrating Scholarship \& Creativity Day 77. 
2. Clauer PJ (2009) Why have my hens stopped laying? Poultry Extension Specialis, Animal and Poultry Sciences.

3. Christensen H, Bisgaard M, Bojesen AM, Mutters R, Olsen JE (2003) Genetic relationships among avian isolates classified as Pasteurella haemolytica, 'Actinobacillus salpingitidis' or Pasteurella anatis with proposal of Gallibacterium anatis gen. nov., comb. nov. and description of 31. additional genomospecies within Gallibacterium gen. nov. Int J Syst Evol Microbiol 53: 275-287.

4. Hussein AH, Ghanem IA, Eid AA, Ali MA, Sherwood JS, et al. (2013) Molecular and phenotypic characterization of Escherichia coli isolated from broiler chicken flocks in Egypt. Avian Dis 57: 602-611.

5. Mellata M (2013) Human and avian extraintestinal pathogenic Escherichia coli: infections, zoonotic risks, and antibiotic resistance trends. Food Pathog Dis 10: 916-932.

6. Dho-Moulin M, Fairbrother JM (1999) Avian pathogenic Escherichia coli (APEC). Veterinary Research, BioMed Central 30: 299-316.

7. Porter ER (1998) Bacterial enteritidis of poultry. Poult Sci 77: 11591165

8. Swayne DE, Glisson JR, McDougald LR, Nolan Lisa, Suarez DL, et al. (2013) Diseases of Poultry. (13 ${ }^{\text {th }}$ edn), Blackwell Publishing Ltd., Iowa, USA.

9. Mushin R, Weisman Y, Singer N (1980) Pasteurella haemolytica found in the respiratory tract of fowl. Avian Dis 24: 162-168.

10. Grimont Pad, Grimont F, Bouvet P (2000) Taxonomy of the Genus Salmonella, In: Salmonella in domestic animals. Wray C, Wray A (Eds.) CABI Publishing, New York, USA, p.1-17, cap.1,
11. Anom (2009) Fowl typhoid and Pullorum disease.

12. Shivaprasad HL (2000) Fowl typhoid and pullorum disease. Rev Sci Tech Off Int Epiz 19: 405-424.

13. Mirle C, Schöngarth M, Meinhart H, Olm U (1991) Studies into incidence of Pasteurella haemolytica infections and their relevance to hens, with particular reference to diseases of the egg-laying apparatus. Monatshe e fuer Vet Med 46: 545-549.

14. Bisgaard M, Korczak BM, Busse HJ, Kuhnert P, Bojesen AM (2009) Classification of the taxon 2 and taxon 3 complex of Bisgaard within Gallibacterium and description of Gallibacterium melopsittaci sp. nov., Gallibacterium trehalosifermentans sp. nov. and Gallibacterium salpingitidis sp. nov. Int J Syst Evol Microbiol 59: 735-744.

15. Neubauer C, De Souza-Pilz M, Bojesen AM, Bisgaard M, Hess M (2009) Tissue distribution of haemolytic Gallibacterium anatis isolates in laying birds with reproductive disorders. Avian Pathol 38: 1-7.

16. Singh AV, Singh BR, Sinha D K, OR VK, Vadhana AP, et al. (2016) Gallibacterium anatis: An Emerging Pathogen of Poultry Birds and Domiciled Birds. J Veterinar Sci Techno 7: 1-7.

17. Gast RK, Shivaprasad HL, Barrow PA (2008) Salmonella infections. Saif YM (Eds.), Disease of poultry $\left(12^{\text {th }}\right.$ edn), Blackwell Publishing, Iowa, USA, pp. 619-674.

18. Van Empel PCM, Hafez HM (1999) Ornithobacterium rhinotracheale: A review. Avian Pathol 28: 217-227.

\section{Your next submission with Juniper Publishers will reach you the below assets}

- Quality Editorial service

- Swift Peer Review

- Reprints availability

- E-prints Service

- Manuscript Podcast for convenient understanding

- Global attainment for your research

- Manuscript accessibility in different formats ( Pdf, E-pub, Full Text, Audio)

- Unceasing customer service

Track the below URL for one-step submission https://juniperpublishers.com/online-submission.php 